\title{
Pengembangan Sistem Manajemen Breeding Sapi Bali
}

\author{
Luqman Hakim, Suyadi, Nuryadi, Trinil Susilawati dan Ani Nurgiartiningsih
}

\author{
Fakultas Peternakan Universitas Brawijaya, Malang
}

\section{INTISARI}

Sebagai plasma nutfah Nasional, keberadaan sapi Bali perlu dipertahankan dan dimanfaatkan secara lestari-produktif; sebab memiliki beberapa keunggulan spesifik. Pengadaan sapi Bali bibit dapat diperoleh melalui pengembangan Village Breeding Center. Namun tampaknya belum ada program pemuliaan yang jelas dan terarah; karena rekording belum dilakukan secara lengkap, benar, dan berkesinambungan. Proyek Perbibitan dan Pengembangan Sapi Bali (P3Bali) yang mengemban memperbaiki mutu sapi Bali dan menghasilkan sapi pejantan unggul, tampaknya belum efektif. Suatu kegiatan dan kajian tentang sistem manajemen breeding sapi Bali (metode survei dan deep interviev) telah dilakukan di P3Bali dan instansi terkait (Agustus - Nopember 2004). Fenotip sapi Bali di P3Bali, di Instalasi Populasi Dasar (IPD) Kabupaten Tabanan dan di Kabupaten Karangasem masih relatif seragam. Pertumbuhan maksimal yang didasarkan ukuran statistik vital (tinggi gumba, panjang badan, lingkar dada) dan bobot badannya, dicapai pada kelompok umur PI-4, dan selanjutnya relatif tidak ada pertumbuhan. Performansnya di IPD dan di Kabupaten Karangasem relatif lebih baik daripada di P3Bali; bahkan selama 9 tahun terakhir menunjukkan kecenderungan yang semakin menurun. Sistem seleksi untuk calon induk atau pejantan telah mengikuti prosedur yang standar (performance test dan progeny test); tetapi tidak ditemukan silsilah dari ternak yang terjaring. Namun kriteria seleksi bobot badan masih sangat longgar $(140-160 \mathrm{~kg})$. Adanya pemasukan sapi baru setiap tahun di P3Bali, dapat menetralisir upaya perbaikan mutu genetik hasil seleksi yang telah terkonsentrasi; sehingga secara time-series tampak tidak ada peningkatan performans produksi. dan mutu genetiknya. Adanya skema breeding di P3Bali yang sudah memenuhi standar, belum banyak diterapkan di lapang. Kurang lengkapnya rekording tidak dapat menghindari inbreeding; dan dengan intensitas seleksi yang rendah, tampak tidak ada kemajuan genetik dalam program seleksi (uji progeni untuk karakter bobot sapih dan bobot badan umur 1 tahun).

Kata kunci : sistem manajemen, breeding, sapi Bali

\section{PENDAHULUAN}

Sebagai salah satu aset Nasional, sapi Bali sebagai plasma nutfah perlu dipertahankan keberadaannya dan dimanfaatkan secara lestari sebab memiliki beberapa keunggulan spesifik; diantaranya mempunyai sifat reproduksi dan kualitas karkas sangat baik, tahan pada kondisi lingkungan tropis dan pakan jelek, serta mempunyai fertilitas yang tinggi. Dibanding dengan sapi potong lokal lainnya, sapi Bali mempunyai performans produksi yang lebih efisien; dengan angka kebuntingan dan angka kelahiran yang tinggi $80 \%$, pertambahan bobot badan dengan pakan yang baik dapat mencapai $0,7 \mathrm{~kg} / \mathrm{hari}$ (jantan dewasa) dan $0,6 \mathrm{~kg} /$ hari (betina dewasa), serta persentase karkas berkisar antara 
51,5 sampai $59,8 \%$, dengan persentase tulang kurang dari $15 \%$ berat karkas, dan dagingnya berkadar lemak rendah (Pane, 1991). Namun, dari aspek perbaikan mutu genetik ternak, selain program pemurnian yang pernah dicanangkan sejak jaman pemerintahan Hindia Belanda, praktis belum ada program pemuliaan yang jelas dan terarah. Upaya yang telah dilakukan selama ini masih bersifat parsial dan sporadis, dengan kegiatan berupa random with no objective selection (Diwyanto, 2003). Kegiatan pencatatan data produksi dan reproduksi belum dilakukan secara lengkap, tertib, benar dan akurat, serta berkesinambungan; serta pengelolaan sumber daya genetik secara baik praktis belum banyak dipahami oleh sebagian besar stakeholder, namun masih merupakan wacana belaka. Oleh karenanya, dalam melestarikan dan mengembangkan sumber daya genetik sapi Bali yang ada di kawasan sumber bibit ternak, secara selektif pemerintah telah mengalokasikan dana pengembangan di lokasi sentra-sentra penyebaran ternak pemerintah (Direktorat Perbibitan, 2001), berupa Proyek Perbibitan dan Pengembangan Sapi Bali (P3Bali) sejak tahun 1976.

Kinerja P3Bali selama 28 tahun yang masih belum menunjukkan hasil maksimal tersebut, dirasa perlu untuk dilakukan: (1) Evaluasi dan analisis yang mendalam tentang program dan kegiatan yang telah dilakukan selama ini; (2) Identifikasi kendala-kendala teknis, prosedural, sosial, dan ekonomis penyebab lambatnya kemajuan proyek, sehingga diperoleh data konkrit sebagai pijakan untuk perbaikan program; dan (3) Pengembangan sistem manajemen perbibitan, dengan menyusun skenario program pengembangan bibit sapi Bali untuk menghasilkan ternak unggul, ditinjau dari aspek pemuliaan ternak, kelembagaan, daya dukung lingkungan, dan sistem pendanaan untuk pelestarian produktif sapi Bali.

\section{MATERI DAN METODE}

Materi yang digunakan dalam penelitian ini adalah 1) sapi Bali pada berbagai kelompok umur, baik yang ada di Pusat Perbibitan Pulukan, maupun yang ada di Instalasi Populasi Dasar Kabupaten Tabanan, di populasi peternakan rakyat Kabupaten Karang Asem, dan di Balai Inseminasi Buatan Baturiti; 2) data sekunder yang berupa Laporan Tahunan P3Bali, Laporan Tahunan Dinas Peternakan (Propinsi Bali, Kabupaten Tabanan, dan Karang Asem) dan dokumen-dokumen yang terkait dengan program breeding di P3Bali, serta data sekunder dan dokumen yang terkait dengan kegiatan P3Bali.

Metode penelitian yang digunakan dalam penelitian ini adalah survei di lapang, dengan lokasi dan materi penelitian diambil secara purposive sampling. Data sekunder dikumpulkan dari berbagai instansi yang terkait dengan P3Bali, untuk dianalisis, dievaluasi, dan diinterpretasikan. Data primer diperoleh dengan cara pengukuran dan pengamatan langsung pada obyek penelitian; sedangkan sebagian data lainnya diperoleh dengan cara wawancara mendalam (deep interview).

\section{Pengukuran Performans Sapi Bali}

Performans produksi yang diukur adalah bobot sapih dan bobot badan umur 1 tahun, sedangkan performans reproduksi sapi Bali diketahui melalui wawancara mendalam dengan para peternak pemilik sapi sebagai responden. Selain itu, performans sapi Bali juga diketahui dari data sekunder (pengukuran sebelumnya) yang terdapat dalam Laporan Tahunan P3Bali yang meliputi $\mathrm{S} / \mathrm{C}$, lama kosong dan selang beranak. 


\section{Evaluasi dan Analisis Program Breeding Sapi Bali}

Sapi Bali yang ada di Instalasi Populasi Dasar (di Kabupaten Tabanan) sebagai dasar program seleksi, diamati secara langsung performansnya dengan mengukur statistik vitalnya (tinggi gumba, panjang badan, lingkar dada) dan menimbang bobot badannya pada berbagai kelompok umur. Jumlah sapi yang diamati adalah semua sapi yang didatangkan ke lokasi contoh yang ikut dalam program penimbangan dan penyuluhan secara rutin oleh $\mathrm{P} 3$ Bali. Wawancara mendalam dengan para peternak sebagai responden (diambil secara purposive sampling), dilakukan untuk mengetahui performans reproduksi sapi Bali di populasi dasar. Pengamatan ini juga didukung dengan data sekunder yang ada di P3Bali, yakni pada Laporan Tahunan (Tahun 1994 - 2003) yang diambil secara total sampling, serta wawancara langsung dengan pimpinan dan staf teknis P3Bali. Dari data primer dan sekunder ini diharapkan dapat mengungkap sistem penjaringan dan jumlah sapi jantan yang terjaring sebagai calon pejantan, yang nantinya dikirim ke Pusat Perbibitan di Pulukan.

\section{HASIL DAN PEMBAHASAN}

\section{Populasi}

Keberadaan sapi Bali di Propinsi Bali menyebar di seluruh Kabupaten, yaitu di Kabupaten/Kota Denpasar, Badung, Gianyar, Klungkung, Karangasem, Bangli, Buleleng, Jembrana dan Tabanan. Berdasarkan data Cacah Jiwa Ternak Propinsi Bali Tahun 2003, populasinya sebesar 539.781 ekor, yang terdiri dari Pejantan 80.630 ekor, Jantan Muda 81.808 ekor, Anak Jantan 65.746 ekor, Jantan Dikebiri 1.349, Induk 175.293, Betina Muda 70.084 ekor, Anak Betina 64.871 ekor. Dibandingkan dengan keadaan tahun 2002 yang populasinya sebesar 521.973 ekor, ada kenaikan populasi sebanyak 3,41\%. Dimasa mendatang diharapkan terjadi peningkatan populasi, sejalan dengan pertambahan penduduk dan meningkatnya konsumsi pangan protein hewani asal ternak, khususnya sapi potong.

\section{Performans Produksi}

Produktivitas ternak dapat dinilai dengan menggunakan ukuran bobot sapih dan bobot badan umur 1 tahun. Berdasarkan data seri (time-series) selama 9 tahun terakhir di Pusat Perbibitan sapi Bali sebagaimana disajikan pada Gambar 1 dan 2, menunjukkan bahwa bobot sapih dan bobot badan umur 1 tahun ada kecenderungan semakin menurun. Pada tahun 1998/1999, bobot sapih dan bobot badan umur 1 tahun ternak jantan maupun betina adalah paling rendah. Menurut Lasley (1978) dan Hickman (1991), bobot sapih merupakan variabel yang baik sebagai parameter seleksi dan penilaian produktivitas ternak, karena mempunyai keragaman yang besar. Selain itu, adanya perbedaan performas pada ternak jantan dan betina, disebabkan oleh adanya interaksi antara gentotipe dengan jenis kelaminnya. Hickman (1991) juga menyatakan bahwa keragaman pertumbuhan ternak setelah lepas sapih sangat besar, dan banyak dipengaruhi oleh faktor lingkungan termasuk kualitas pakan yang diberikan. 


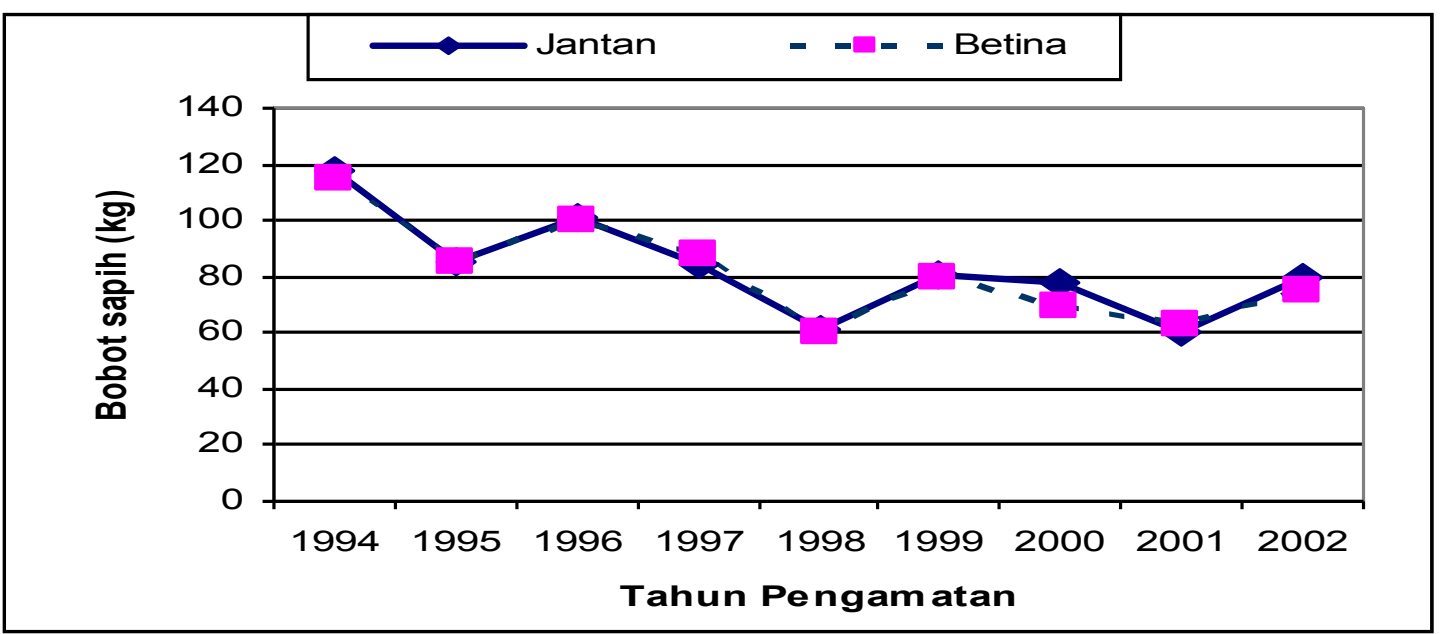

Gambar 1. Grafik Rata-Rata Bobot Sapih Sapi Bali Jantan Dan Betina Selama Kurun

Waktu 9 Tahun Terakhir (1994 sampai 2002)

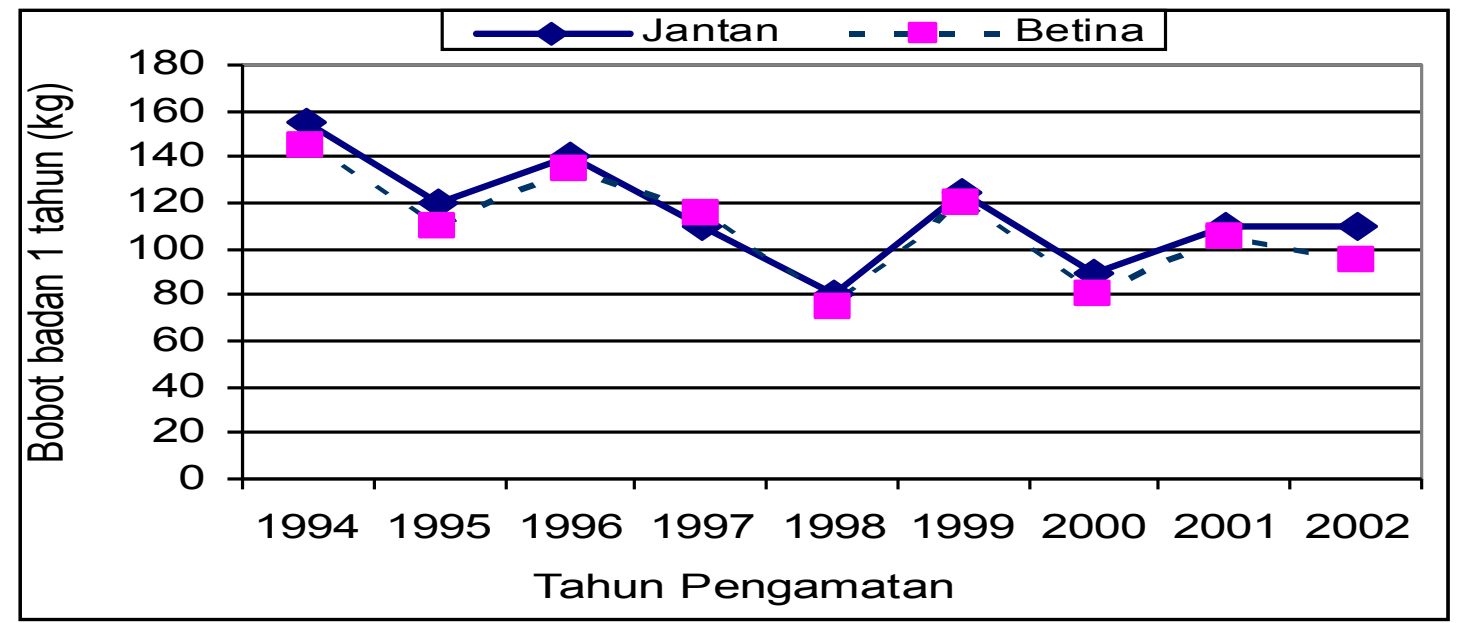

Gambar 2. Grafik Rata-Rata Bobot Badan Umur 1 Tahun Sapi Bali Jantan Dan Betina Selama Kurun Waktu 9 Tahun Terakhir (1994 sampai 2002)

\section{Performans Reproduksi Sapi Bali}

Hasil penelitian menunjukkan bahwa sistem perkawinan sapi Bali di Kabupaten Tabanan dan Karang Asem sebagian besar adalah secara alami dengan menggunakan sapi pejantan setempat (Kabupaten Tabanan 88,2\%, dan Kabupaten Karang Asem 72,4\%); sedangkan sebagian kecil sisanya mengawinkan sapinya dengan Inseminasi Buatan (IB), yang semen bekunya berasal dari Unit Pelaksana Teknis Daerah Balai Inseminasi Buatan
(BIB) Baturiti. Di Pusat Perbibitan, sistem perkawinan ternak dilakukan dengan kombinasi cara alami maupun IB, yang semen bekunya berasal dari BIB Singosari.

Service per conception (S/C) sapi Bali di Kabupaten Tabanan adalah 1,02, dan di Kabupaten Karang Asem 1,16; sedangkan di Pusat Perbibitan tidak tersedia data. Days open sapi Bali di Kabupaten Tabanan adalah 117,39 hari, dan di Kabupaten Karang Asem 106 hari; sedangkan di Pusat Perbibitan juga tidak tersedia data. 


\section{Seleksi di Instalasi Populasi Dasar}

Seleksi yang dilakukan di tingkat Instalasi Populasi Dasar dilaksanakan terhadap sapi yang berada di bawah pembinaan P3Bali yang dimiliki peternak plasma. Peternak plasma ini berlokasi di Kabupaten Tabanan dengan melibatkan empat kelompok peternak yang berada di Kecamatan berbeda dan mewakili daerah dengan ketinggian tempat dan agroekosistem yang dianggap berbeda. Kecamatan tersebut adalah Baturitti (daerah dataran tinggi), Penebel (daerah dataran sedang), serta Selamadeg dan Marga (daerah dataran rendah). Dalam upaya untuk mengembangkan komunitas/populasi dasar sebagai sumber genetik sapi Bali yang akan dibawa ke Pusat Perbibitan, pihak P3Bali memberikan paket kredit kepada peternak, dengan tujuan untuk: meningkatkan pendapatan peternak; dan membentuk jejaring/ikatan antara peternak plasma yang dibina dengan peternakan inti di Pusat Perbibitan agar beberapa ternak (jantan maupun betina) yang terpilih sebagai calon pejantan dan calon induk dapat dengan mudah dialirkan ke Pusat Perbibitan di Pulukan. Dengan adanya peternakan plasma diharapkan pihak P3Bali dapat dengan mudah melakukan seleksi untuk penjaringan calon pejantan dan calon induk yang merupakan keturunan dari sapi Bali yang diserahkan kepada peternak plasma. Di tingkat IPD, seleksi (atau lebih tepatnya disebut pemilihan ternak) dilakukan terhadap calon induk yang akan diserahkan kepada peternak penerima kredit (peternak plasma), yang berarti dilaksanakan saat realisasi kredit. Data yang tersedia di lapang menunjukkan bahwa seleksi hanya dilakukan terhadap calon induk (meskipun ditemukan pula kredit untuk pejantan) yang didasarkan atas bobot badan (BB), yaitu untuk calon induk yang memiliki bobot badan 140 sampai $160 \mathrm{~kg}$ dinyatakan lolos seleksi tanpa mempertimbangkan faktor umur. Kriteria seleksi ini tentu saja sangat longgar apabila dibandingkan dengan hasil survei terhadap sapi Bali yang dilakukan Talib et al. (2002) di beberapa wilayah Indonesia timur. Hasil tim tersebut menunjukkan rata-rata $\mathrm{BB}$ saat pubertas sapi Bali di NTT, NTB, Bali dan Sulsel masing-masing adalah 179,8; 182,6; 170,4; dan 225,2 kg; sedangkan BB dewasa untuk wilayah yang bersangkutan masing-masing adalah 221,5; 241,9; 303,3 dan 211,0 kg. Dengan adanya kriteria seleksi yang diterapkan di tingkat peternak plasma (berdasarkan BB 140 sampai $160 \mathrm{~kg}$ ), maka ada dua kemungkinan yang dapat terjadi, yaitu: (1) Apabila calon induk yang lolos seleksi telah mengalami dewasa kelamin (sexual maturity), maka dapat diduga bahwa sapi tersebut memiliki kualitas genetik yang kurang menguntungkan untuk dijadikan calon bibit; dan (2) Apabila yang lolos seleksi berlum mengalami pubertas, maka peternak penerima kredit akan menunggu waktu yang cukup lama sampai sapinya mencapai pubertas dan siap untuk dikawinkan (telah dewasa tubuh). Dalam hal ini akan berpengaruh terhadap keuntungan peternak yang seharusnya diterima, dan juga berpengaruh terhadap kelancaran program di Pusat Perbibitan. Berdasarkan data yang tersedia di P3Bali, calon induk yang terseleksi dan akan diserahkan kepada peternak plasma oleh P3Bali, berkisar antara 87 sampai 95\% (Tabel 1).

\section{Seleksi di Pusat Perbibitan Pulukan P3BaliBerdasarkan Uji Performans}

Sejumlah sapi jantan muda hasil seleksi di Instalasi Populasi Dasar kemudian dikirim ke Pusat Perbibitan Pulukan untuk dipelihara dalam kondisi 
yang sama, dan kemudian dilakukan uji peformans untuk dipilih 5 sampai 6 ekor yang memiliki bobot badan terberat. Dari jumlah sapi yang terpilih, 1 sampai 2 ekor terbaik akan tetap dipelihara sebagai calon pejantan unggul yang akan digunakan untuk uji keturunan (progeny test). Pejantan yang telah lulus progeny test selanjutkan dikirim ke BIB Singosari; sedangkan sisanya 2 sampai 6 ekor dikirim kembali ke peternak plasma untuk digunakan sebagai pemacek induk yang ada (Tabel 2).

Untuk menghasilkan pejantan unggul sapi Bali di Pusat Perbibitan, dilakukan uji performans yang didasarkan pada bobot badan tertentu calon pejantan. Hardjosubroto (2000) menguraikan bahwa pada dasarnya uji performans merupakan cara yang praktisdan tepat untuk memilih calon pejantan dan induk pengganti dalam suatu stasiun perbibitan atau BIB dalam rangka untuk meningkatkan mutu genetik ternak. Namun seleksi tersebut harus pula diikuti dengan pengujian mutu genetiknya. Hal ini dapat diduga dari penampilan bapak dan induknya, terutama untuk sifat-sifat yang memiliki heritabilitas tinggi, seperti bobot sapih dan bobot badan umur 1 tahun.

Tabel 1. Seleksi/Penjaringan dan Culling Calon Induk dan Pejantan di IPD Tahun 1994 sampai 2003

\begin{tabular}{cccccc}
\hline \hline Tahun & $\begin{array}{c}\text { Seleksi }^{1} \\
\text { N (Ekor) }\end{array}$ & $\begin{array}{c}\text { Betina culling }^{2} \\
\text { N (Ekor) }\end{array}$ & $\begin{array}{c}\text { Pejantan } \\
\text { Baru }^{3} \text { (Ekor) }\end{array}$ & $\begin{array}{c}\text { Culling Pe- } \\
\text { jantan }^{4} \\
\text { (Ekor) }\end{array}$ & $\begin{array}{c}\text { Pejantan } \\
\text { Muda }^{5} \\
\text { (Ekor) }\end{array}$ \\
\hline 1994 & $432(87 \%)$ & $13(0,83 \%)$ & 14 & 9 & 28 \\
1995 & $600(92,02 \%)$ & $13(0,67 \%)$ & 11 & 8 & 15 \\
1996 & $788(90,88 \%)$ & $31(1,29 \%)$ & 15 & 16 & 12 \\
1997 & $186(95,38 \%)$ & $16(0,77 \%)$ & 1 & 7 & 29 \\
1998 & - & $21(1,28 \%)$ & 5 & 15 & 5 \\
1999 & $106(92,17 \%)$ & $4(0,32 \%)$ & 3 & 11 & 6 \\
2000 & $106(92,17 \%)$ & $7(0,67 \%)$ & 0 & 3 & 6 \\
2001 & - & - & 4 & - & 4 \\
2002 & - & - & 1 & 1 & 20 \\
2003 & - & - & 2 & 6 & 25 \\
\hline Ken & & & & & \\
\hline
\end{tabular}

Keterangan:

1) Seleksi atau pemilihan calon induk yang disediakan oleh pedagang pada saat realisasi kredit kepada peternak.

2) Jumlah sapi betina yang berada di peternakan plasma yang di culling dari populasi per tahun, dengan alasan kemampuan produksi yang tidak normal, misalnya karena: umur terlalu tua, bobot badan terlalu rendah, infertil atau repeat breeding (dikawinkan 3 kali berturut-turut tidak bunting).

3) Jumlah pejantan baru sebagai pemacek (untuk kawin alam) yang dimasukkan ke Instalasi Populasi Dasar (umumnya berasal dari pasar).

4) Pejantan yang dikeluarkan dari populasi dasar dengan alasan kegemukan atau libido rendah.

5) Jumlah jantan muda hasil seleksi di tingkat Instalasi Populasi Dasar untuk dikirim ke Pusat Perbibitan Pulukan. Seleksi dilakukan berdasarkan bobot badan umur 1 tahun. Sapi jantan terseleksi apabila memiliki bobot badan di atas rata-rata populasi. 
Selama kurun waktu tahun 1994 sampai 1998 telah dihasilkan sepuluh ekor pejantan unggul yang ditempatkan di Pusat Perbibitan dan 18 ekor pejantan yang dikembang- biakkan di peternakan plasma binaan. Setelah kurun waktu tersebut sampai tahun 2003, seleksi untuk menghasilkan pejantan tidak dilakukan karena menjangkitnya wabah penyakit Jembrana (Tabel 2).

Dari Tabel 1 dan 2 tampak terjadinya aliran genetik calon pejantan dari populasi dasar, walaupun belum diketahui secara pasti apakah kualitas genetik dan performans fenotipik ternak tersebut lebih bagus daripada calon pejantan hasil keturunan induk yang ada di Pusat Perbibitan. Apabila seleksi di Pusat Perbibitan dilakukan secara teratur dan kontinyu untuk menghasilkan keturunan yang akan diseleksi lagi untuk menghasilkan calon induk dan pejantan yang akan digunakan sebagai pengganti generasi sebelumnya, maka dapat diharapkan bahwa performans (bobot sapih dan bobot badan umur 1 tahun) sapi yang ada dalam Pusat Perbibitan dari tahun ke tahun atau dari generasi ke generasi akan mengalami kenaikan sampai mencapai suatu titik optimal tertentu. Namun hal yang sebaliknya justru ditemukan di Pusat Perbibitan Pulukan, dimana rata-rata performans bobot sapih dan bobot badan umur 1 tahun dari sapi atau keturunannya cenderung mengalami penurunan dari tahun 1994 sampai tahun 2002.

Tabel 2. Seleksi Berdasarkan Uji Performans Untuk Menghasilkan Pejantan Unggul di Pusat Perbibitan Pulukan Tahun 1994 sampai 2003

\begin{tabular}{cccc}
\hline \hline \multirow{2}{*}{ Tahun } & $\begin{array}{c}\text { Jumlah Calon } \\
\text { Pejantan (Ekor) }\end{array}$ & \multicolumn{2}{c}{ Pejantan terseleksi ditempatkan di } \\
\cline { 3 - 4 } & & $\begin{array}{c}\text { Pusat Perbibitan } \\
\text { (Ekor) }\end{array}$ & $\begin{array}{c}\text { Instalasi Populasi Dasar } \\
\text { (Ekor) }\end{array}$ \\
\hline 1994 & 41 & $1(2,43 \%)$ & $4(9,76 \%)$ \\
1995 & 47 & $2(4,26 \%)$ & $6(12,77 \%)$ \\
1996 & 42 & $2(4,76 \%)$ & $6(14,29 \%)$ \\
1997 & 35 & $2(5,72 \%)$ & $2(5,71 \%)$ \\
1998 & 27 & $3(11,11 \%)$ & 0 \\
1999 & 22 & Tidak ada seleksi pejantan karena ada wabah \\
2000 & 13 & \multicolumn{2}{c}{ penyakit Jembrana } \\
2001 & - & \multicolumn{2}{c}{ Tahap persiapan } \\
2002 & 24 & 0 & 0 \\
2003 & 34 & \multicolumn{2}{c}{0} \\
\hline
\end{tabular}

Berdasarkan Uji Keturunan (Progeny $\underline{\text { Test) }}$

Uji keturunan adalah penggunaan catatan dari hasil keturunannya untuk memperkirakan nilai pemuliaan seekor ternak (Warwick et al., 1984). Sebagaimana disajikan pada Tabel 2, jumlah calon pejantan yang terseleksi dan akan dipilih sebagai pejantan unggul di tingkat Pusat Perbibitan adalah 2 sampai
3 ekor. Setelah dapat ditetapkan sapi pejantan unggul berdasarkan uji performans, maka program berikutnya adalah melakukan uji keturunan untuk memilih satu pejantan yang paling unggul untuk selanjutnya dapat dikirim ke BIB sebagai pejantan penghasil semen. Berdasarkan data yang ada (P3Bali, 2002), sejak berdirinya P3Bali telah dihasilkan 16 ekor pejantan unggul, dimana 10 ekor layak untuk dikirim ke Balai Inseminasi 
Buatan Singosari; sedangkan sisanya (6 ekor) terbukti sero-positif penyakit Jembrana.

Dalam program progeny test, 2 sampai 3 pejantan terpilih dikawinkan dengan sejumlah betina induk yang ada di Pusat Perbibitan, dan diamati performans anak/keturunan yang dihasilkan. Sebagai pembanding, betina induk yang ada juga di inseminasi dengan semen yang diproduksi Balai Inseminasi Buatan Singosari, dimana pejantannya juga berasal dari hasil uji keturunan di P3Bali pada tahun sebelumnya.

Prosedur penentuan pejantan unggul melalui uji performans dan dilanjutkan dengan uji genetik, baik dengan penelurusan kemampuan induk dan bapak maupun uji keturunan, merupakan metode yang cukup akurat dalam memilih pejantan unggul untuk penggunaan selanjutnya dalam skala yang lebih luas, misalnya sebagai sumber semen (Hardjosubroto, 2000). Prosedur ini sangat penting dan memberikan makna bahwa sifat individu yang diuji memberikan kesan seekor ternak seperti yang tampak; sedangkan silsilahnya menyatakan bagaimana potensi seharusnya individu tersebut, tetapi tampilan keturunannya menyatakan keadaan yang sebenarnya dari individu (Warwick, dkk., 1984). Dengan terbatasnya jumlah induk yang digunakan per pejantan, dan juga jumlah anak jantan maupun betina dari induk dalam pejantan yang sama, sebagaimana disajikan pada Tabel 8 tampak bahwa tidak ada konsistensi nilai keunggulan keturunannya (dalam hal bobot sapih maupun bobot badan umur 1 tahun), baik dari keturunan hasil inseminasi buatan atau dari pejantan peserta uji keturunan selama kurun waktu 9 tahun (tahun 1994/1995 sampai 1999/2000). Nilai-nilai pengukuran (bobot sapih dan bobot badan umur 1 tahun anak jantan maupun betina) juga menunjukkan tidak adanya perbedaan yang signifikan antar pejantan pada setiap tahunnya. Hal ini menunjukkan bahwa tidak ada peningkatan keunggulan yang berarti dari sapi calon pejantan untuk mewariskan sifat kepada anaknya dari tahun ke tahun. Dengan berlangsungnya program breeding (uji keturunan) di Pusat Perbibitan P3Bali, tampaknya belum ada peningkatan performans produksi yang berarti, walaupun heritabilitas sifat bobot sapih dan bobot badan umur 1 tahun termasuk kategori tinggi (Warwick et al., 1984; Hardjosubroto, 1994).

Dari Tabel 2, secara time-series tampak bahwa sifat bobot sapih dan bobot badan umur 1 tahun anak dalam progeny test ada kecenderungan menurun. Kecenderungan ini kemungkinan disebabkan pejantan perserta progeny test bukan merupakan hasil seleksi terbaik dari sekelompok keturunan di Pusat Perbibitan, tetapi berasal dari penjaringan di peternakan plasma (IPD). Dengan demikian tidak dapat diketahui secara pasti bagaimana silsilah dan kondisi lingkungan awal sapi jantan yang terjaring, yang mungkin berbeda sama sekali dengan kondisi lingkungan di Pusat Perbibitan. Selain itu, penjaringan sapi calon pejantan oleh P3Bali hanya dilakukan dalam periode waktu tertentu saja, sehubungan dengan ketersediaan anggaran setiap tahun, yakni pada bulan Juli sampai Agustus. Oleh karena itu, apabila di peternakan plasma ada sapi jantan berkualitas baik pada saat-saat diluar periode waktu tersebut, maka tidak dapat dijaring oleh pihak P3Bali, dan oleh pemiliknya terpaksa dijual ke pasar.

\section{KESIMPULAN}

Pertumbuhan maksimal sapi Bali dicapai pada kelompok umur PI-4, dan pada kelompok umur selanjutnya relatif tidak ada pertumbuhan (ukuran statistik vital dan bobot badannya relatif tetap). 
Performans produksi, yaitu bobot sapih dan BB umur 1 tahun sapi Bali yang ada di Pusat Perbibitan Pulukan selama 9 tahun terakhir menunjukkan kecenderungan yang semakin menurun. Performans reproduksi sapi Bali yang ada di IPD Kabupaten Tabanan dan Karang Asem termasuk kategori baik dan menunjukkan tingkat fertilitas yang tinggi; dengan nilai $\mathrm{S} / \mathrm{C}$ 1,02 sampai 1,16 dan Days Open 106 sampai 117 hari, walaupun sekitar 72,4 sampai $88,2 \%$ perkawinannya dilakukan secara alami dengan pejantan lokal. Sedangkan di Pusat Perbibitan Pulukan tidak tersedia data. Sistem seleksi/penjaringan sapi Bali sebagai calon induk atau pejantan di populasi dasar maupun di Pusat Perbibitan Pulukan, pada dasarnya telah mengikuti prosedur yang standar (yaitu performance test dan progeny test), meskipun tidak ditemukan silsilah dari ternak yang terjaring. Skema program breeding yang dicanangkan P3Bali sudah memenuhi standar yang benar; namun dalam kenyataannya di lapang, masih banyak kegiatan yang belum dilakukan sesuai dengan perencanaan. Dengan intensitas seleksi yang rendah dalam menghasilkan sapi Bali pejantan unggul, tampak bahwa tidak ada kemajuan genetik selama 9 tahun terakhir dalam program seleksi di Pusat Perbibitan Pulukan yang didasarkan atas uji progeni, khususnya untuk karakter bobot sapih dan BB umur 1 tahun.

\section{DAFTAR PUSTAKA}

Direktur Perbibitan. 2001. Kebijaksanaan Perbibitan Nasional. Makalah Pertemuan Koordinasi dan Evaluasi Kebijaksanaan Perbibitan di Solo Tanggal 24 - 26 September 2001. Direktorat Perbibitan, Direktorat Jenderal Bina Produksi Peternakan, Departemen Pertanian, Jakarta.

Dwipa, I.B.G. dan B.D. Sarwono, 1992. Musim dan Bobot Badan Sapi Bali yang Di-antar-pulaukan dari Lombok. Jurnal Penelitian Universitas Mataram, NTB. I(2):1 10.

Hakim, L., Nuryadi, Suyadi, T. Susilawati, dan V.M.A. Nurgiartiningsih. 2004. Pengembangan Sistem Manajemen Breeding Sapi Bali. Laporan Kerjasama Teknis Antara Fakultas Peternakan Universitas Brawijaya Dengan Proyek Pembinaan Peningkatan Produksi Peternakan Tahun Anggaran 2004. Fakultas Peternakan Universitas Brawijaya, Malang.

Hardjosubroto, W. 1994. Aplikasi Pemuliabiakan Ternak di Lapangan. PT Gramedia Widiasarana Indonesia, Jakarta. 